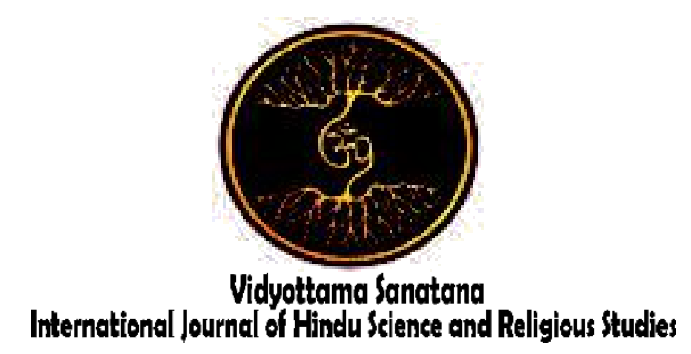

Vol. 2 No. 2 October 2018

\title{
Descriptions Of Aliens (Extraterrestrial Beings) In Vedic Scriptures
}

\author{
By: \\ I.B. Arya Lawa Manuaba ${ }^{1}$, I Nyoman Sudirman ${ }^{2}$ \\ ${ }^{1}$ English Education Department STKIP Suar Bangli, Bali \\ ${ }^{2}$ Elementary School Teacher Education Department STKIP Suar Bangli \\ E-mail: aryamanuaba@stkipsuarbangli.ac.id
}

\begin{abstract}
Polemics emerge when religion is faced to the fact that there are supposedly visitation of intelligent beings from other planets in many cases from ancient times up to now. Vedic literature as basis of Hindu religious teachings is one of many religious resources which can be used as reference to this inquiry. This descriptive-qualitative study aims to (1) clarify whether Vedic Scriptures mention about extraterrestrial life, or intelligent life outside Planet Earth, and (2) enlist categories of extraterrestrial life as mentioned in the Vedic Scriptures. The methods used are literature study and documentary. Result of the study reveals that Vedic Scriptures, especially the four Vedas, Puranas and Itihasas clearly mention about existence of extraterrestrial species (alien beings) and their interactions with humans since the Vedic era. These extraterrestrial beings are of different categories which are more elaborately enlisted in some major Puranic literatures.
\end{abstract}

Keywords: extraterrestrial, alien, Vedic scriptures.

\section{Introduction}

Sometimes there is a big gap between science and religion on the basis of liability of a phenomenon to be properly proven (Thompson, 1995). Science deals with systematic thought, following certain rules and methods to prove and examine. In the other hand, religion is mostly imbued with faith which often leads to unchangeable dogmatic perspective. Since then, religion is always connected to vested and ascribed patterns of thought and thus labelled as being bias to scientifically explain why something is believed and conducted.

The Vedic system of belief, however, is not based on dogmas. The word veda itself means 'knowledge' (Thakura, 2006) and thus Veda is actually a compilation of knowledge, or vidyas. Therefore, Veda does not exist in the form of a book, but 
collections of revealed knowledge instead. According to its objects, there are two categories of knowledge namely para-vidya (knowledge about reality beyond sensual perception and human logic) and aparavidya (knowledge about material reality) (Singh, 2010). Math, chemistry, physics, social science, and health science are included in apara-vidya section, whereas knowledge on the nature of difference between material symptoms and spiritual reality is known as para-vidya. For instance, procedural knowledge of how someone boils a cup of coffee is apara-vidya, while subtle science on difference between coffee seeds (which is a living entity) and a piece of abiotic rock is para-vidya.

Bhagavad-gita, the most prominent and well-known Hindu scripture defines characters of para-vidya knowledge as guhya, guhyataram and guhyatamam,confidential, more confidential and the most confidential (Prabhupada, 2009: 190). The reason why this para-vidya is called confidential is that since it is unobservable through common sensual perception and logic only. This level of knowledge is also called guhyataram 'more confidential' and guhyatamam 'the most confidential' for it can only be fully received if somebody approaches what is called a knowledge authority. In Sanskrit terminology, this authority of knowledge is known as ācārya, 'spiritual mentor'. To attain complete and perfect knowledge, therefore, the Vedic Scriptures themselves offer three methods to receive knowledge. These three Vedic methods are known as tri pramana.

Since the Vedic Scriptures are knowledge accepted by either one, two or three pramana methods, all knowledge present in themselves are not dogmatic, but scientific (Singh, 2010: 23). Therefore, Vedic Scriptures contain available knowledge sufficient for fulfilling human inquiry, ranging from basic inquiry to the topmost ones (Prabhupada: 2003a), as stated in the Vedanta-sutra by the verse athato brahma jijnasa. In the Mahabharata, Adiparva Section it is mentioned that anything stated in the Vedas truly exist in this universe, but anything which do not exist in the Vedas are in fact nonexistent (Thompson, 2010: 23).

One of intriguing scientific issues which has become major polemic in its relation to religion is the existence of extraterrestrial life, which is broadly known as aliens in common. Scientific communities have been pushed to study about possibility of extraterrestrial life since emergence of frequent unexplainable cases of abduction, cattle mutilation, disorientation and hallucination in the US during the 40s and 80 s, or during and after the World War 2. In order to examine those strange phenomena, the government of the US established Project Blue Book in 1952, which successfully collected more than 5,000 cases of alien sightings, encounters and abductions in the US only (Hidel, 2016). UFO and alien observers emerged in the US in the 60s and after UFO phenomena became worldwide issue in 1980s, a lot of UFO researchers started to thrive around the globe.

Center of UFO Studies in Illinois, US reported that until 1981 there had been investigations for over 60,000 UFO and alien cases from 113 nations worldwide. From those cases, 2,000 of them are close encounters to biological and non-biological entities of extra-earth origin, 200 cases are of alien abductions and the rest are of UFO and alien sightings. Further investigations about those phenomena were conducted by J. Allen Hynek (1910-1986) who proposed five categories of alien encounters, known broadly as CE (Close Encounters). Later, the $\mathrm{CE}$ categories were broaden into 8 kinds by subsequent UFO researchers as a posthumous tribute to him.

There are thousands of UFO and alien cases falling into each category, starting from 1 to 8 during three decades from 1940s to 1990 s. This brought a massive shock to both scientific and religious communities. When some prominent UFO and alien researchers came up with study results and books about alien and UFO phenomena, there were apparent contradiction and 
confrontation with the religious parties especially related to origin of human species and the existence of intelligent life outside Earth which are contrary to religious dogmas.

Thus, religious communities are even now still being within unclear attitude between belief which is to be strictly followed as well as preserved and undeniable facts. Meanwhile, scientific communities have presented scientific probabilities though are still skeptical and unable to fully convince people about phenomena unmeasurable via available scientific instruments. If religious parties do not go hand in hand with science in concluding this matter into serious answer and presenting itself as knowledge entity parallel to dogmatic perspective, there will be serious doubts towards religious principles which are believed to be revealed from God, the source of all knowledge. Doubts to religious principles will result in moral degradation and ignorance of the population.

Considering persisting ambiguity in either scientific field or religion regarding the existence of extraterrestrial beings, serious studies are needed. Besides being fantastic, outstanding and unique, this kind of research can prove the ability and reliability of the Vedic Scriptures to fulfill humans' needs of knowledge and enlightenment. In the other side, since the Vedic Scriptures are a system of knowledge, then it is certain that Vedic Scriptures can become a comprehensive resource in both literature studies and historical accounts regarding non-earth originated entities.

\section{Theoretical and Empirical Reviews 2.1 Reviews on relevant theories and bibliographies}

Existence of life outside the Earth is revealed in many parts of Vedic Scriptures. One prominent verse is taken from the Padma Purana:

jalajā nava-lakṣāṇi sthāvarā lakṣa-vimíati | krmayo rudra-sañkhyakāh pakṣiṇām daśalakșanam | trimśal-lakṣāṇi paśavah catur-lakṣāṇi mānuṣāḥ \|

"There are 900,000 species living in the water. There are also 2,000,000 non-moving living entities (sthâvara) such as trees and plants. There are also 1,100,000 species of insects and reptiles, and there are 1,000,000 species of birds. As far as quadrupeds are concerned there are 3,000,000 varieties, and there are 400,000 humanoid species."

Meanwhile, more famous Vedic Scriptures as Mahabharata and Ramayana clearly mention about interspecies wars happening in the far past. There are descriptions of wars between demigods (devas) and demons (asuras) of different shapes and types. In the Mahabharata, there is a description about Arjuna killing Nivatakavaca demons who resided underwater and flied with their advanced space crafts.

In the Bhagavata Purana, Canto 10, Chapter 76, it is mentioned about a war between mischievous King Salva and the inhabitants of Dvaraka. Although alien entities were not mentioned in the chapter, it does state about flying saucer with extraordinary technology and weaponry uncommon to human race.

The Valmiki Ramayana, Sundara Kanda Section, Chapter 8, Verse 6 vividly mentions an alien race called the bhutaganas who controlled Ravana's flying machine. The verse is as follows:

vahanti yam kuṇ̣̂ala-śobhitānanā mahāśanā vyomacarā niśācarāh | vivrtta-vidhvasta-viśála-locanā mahājavā bhūtagaṇạh sahasraśạ̣\|

"Those wonderful vimana air crafts roamed the sky with extremely high speed, controlled by thousands of evil creatures with big round eyes, with helmets on their heads."

A lot more evidence are stated in various parts of the Vedic scriptures. Those descriptions suggest an influence of 
extraterrestrial civilization to human advancement in the past.

\subsection{Empirical studies}

Some notable empirical studies about extraterrestrial life forms lay on cases of alien encounters and abductions, research on supposedly advanced ancient civilizations and anomalous artefacts around the world. Alien encounter and abduction cases range from first to eighth category as per Hynek (1952). Most cases happen in the US and the Meso-America, involving UFO sightings, seeing non-human UFO crews, abduction, surgery without anesthetic procedure, revelation of knowledge, mind control, brainwashing, taking and sampling of bodily tissue and fluids, and even sexual intercourse between human and extraterrestrial being. Research on ancient advanced civilization are conducted for instance by Sitchin (2002) and Daniken (1979), focusing mainly on technology, language and architecture of ancient human civilizations. Those studies are tightly related to anomalous artefacts discovered in ancient sites. Daniken (1979) defines anomalous artefacts as those cultural artefacts which do not match the mainstream historical timeline. The Dropa stones, discovered in China in 1962, are ones of many other anomalous artefacts found by historians that suggest the existence of alien influence in human society. Further studies of the Great Pyramid of Giza also opens new possibility of advanced anomalous architectural engineering back to 3,000-5,000 years before modern machines were invented.

\section{Result and Discussion \\ 3.1 Vedic perspective of extraterrestrial beings}

Referring back to Bhagavad-gita, Chapter 3, it is mentioned that the universal manifestation was created by Brahma and all living entities were made existent by the energy of the Supreme God thorugh the Prajapatis. Prajapatis are primordial living entities created by Lord Brahma to fill the universe with various kinds of living entities according to their specific activities and features (Prabhupada, 2002b: 56).

Since all living entities were created by Prajapatis, all living entities were basically interrelated each other. In the other words, all living entities sustain in one another in a great circle of mutual symbiosis called pravartitam cakram (Bhagavad-gita 3.16). Thus, all living entities in different planets, be they demigods or demons, humans or animals, are originated from one spiritual quality.

This spiritual quality is called atma, or spirit soul. The Vedic scriptures describe spirit soul's attributes and characteristics in vivid ways through elaborate depictions and examples in the Upanishads and Puranas. Since atma is superior to all material conditions, atma is unchanged by any material influences. Based on this substantial characteristic of an atma, it is concluded that atmas also exist within the hot sun, cold moon, windy Saturn, high-pressured Venus and dark Pluto. Those atmas enter a particular body of a particular species according to its karma (activities) and guna (modes of nature which influence the pure spiritual state of the atma itself). Due to different gunas and karmas, each and every atma in this material universe enter different material bodies of different compositions in different planets. Therefore, the Vedic Scriptures describe atma as sarva-gatah, or 'existing anywhere in the universe'. Based on this status, existence of life in other planets is undeniable according to Vedic Scriptures.

Karma and guna determine taxonomy of living entities in the universe. Referring back to Padma Purana [see Section II] about the amount of species in the universe, the taxonomy is clearly defined. Because atma's quality is uninterrupted and undiminished by any material disturbances in this universe, atma can enter any particular material bodies with any material compounds. If atmas reside in the sun, the composition of their material body will be mainly of hydrogen and helium. If the atmas exist on Earth, their material bodies will adjust to the Earthly 
environment. Therefore, according to Vedic Scriptures, existence of life is determined by the presence of atmas, and wherever atmas enter a material body, material life begins.

\subsection{Major classification of extraterrestrial beings in Vedic Scriptures}

Classification of taxonomy of extraterrestrial living entities (aliens) is based on descriptions in the Padma Purana. Major classifications of aliens are based on (1) dominant gunas (mode of nature, whether they are sattvic, rajasic or tamasic), (2) physiology and origin; (3) realms (heavenly, earthly or subterranean); and (4) chemical compounds that build their molecular basis.

\section{Classification based on dominant gunas}

Extraterrestrial beings (aliens) are categorized into three major types, namely the suras (benevolent beings), manusas (mortal human beings) and asuras (malevolent beings). It is based on dominant modes that influence their mentality, whether it is sattvika (goodness), rajas (passion) and tamasika (ignorance). Animals and plants do not specifically fall into this classification, but other texts such as Ayurvedic texts do mention about plants and animals with sattvic, rajasic or tamasic. This classification is a general divisions among good and bad intelligent life in the universe. The demigods, siddhas, caranas, and vidyadharas are classified as suras, while demons such as the bhutas, pisacas, reptilians, and goblins are classified as asuras. In between, the human beings, struggle to be free from asura influences to elevate themselves to heavenly realms with sura qualities.

2. Classification based on physiology and origin

The lowest kinds of living beings are said to depend on water when they breathe. This type of living beings is called the jalajas (aquatic and amphibians). According to Backster (2003), in different planets with suitable intensity of abiotic components, living entities can grow into more intelligent and complex beings. For instance, a reptile on Earth can grow into intelligent reptiles in a more suitable planet with more suitable atmosphere, sun rays, soil condition and oxygen level. So, intelligent alien life can truly exist on other planets although on Earth they may not grow in maximum rate due to unsuitable abiotic conditions.

Krimayas are bacteria, viruses, mono cellular beings, mollusks, larvae, and worms. In other planets there are alien beings of this type who could think as human beings do. They build cities and roam the space with space crafts. In the Atharvaveda it is mentioned about this type of extraterrestrial beings who fall on Earth and create disturbances. The krimayas are afraid of hot temperature, therefore their origin planets are naturally damp and dark.

Sarabhas are family of the krimayas, in the forms of insects and arachnids. They thrive in optimal expressions on a planet with a high oxygen level. The more oxygen they get, the bigger and more intelligent they become. The Bhagavata Purana mentions about ruru species which belongs to krimaya. It is mentioned in the Bhagavata Purana that rurus do not exist on Earth, but more ferocious than a snake.

Sthavaras, or the plants. Their actual habitat is said to be on the moon. Because moon is described as a cooling and fertile place (as per Visnu Purana, Padma Purana and Garuda Purana), plants naturally grow very well there. Sthavaras can heal any disease and are connected tightly to water and carbon. Some plants which produce medical substances, fruits and edible leaves can absorb moon light and turn it into tasty and nutritious compounds.

Rudranas, popular as the reptilian species. Reptilians are included in the asura clan, often remarked as malevolent to other living entities. Siva Purana, Lingga Purana as well as the Mahabharata frequently mention in many parts about malevolent activities of the reptilian races throughout Vedic history. Their clans are known as the nagas and uragas, and they have interactions with humans in the past. In the Mahabharata, it is mentioned that Arjuna married Ulupi, a 
naga prince. Then, the Siva Purana mentions about naga species who resided beneath Hindian Ocean and abducted humans for sustenance. One day they kidnapped a brahmana. This brahmana appealed for help to Lord Siva. Lord Siva then destroyed all the evil nagas and thus he is known as Nagesvara.

Pasunas, or mammals. Some pasuna species are in the form of half lion or half cow. Meanwhile, paksinas, or avian species. They reside on a planetary cluster called Kinnaraloka in the Bhuvarloka section of the universe. They have wings and feather, but they also can think and speak as humans do. Paksina species depend on sun rays and a lot of oxygen.

Manusah, or humanoids. Among the humanoids are human beings, devas, asuras, kinnaras (half human and half beast), kimpurusas (ape-like creatures), gandharvas (heavenly musicians), apsaras (angels), vidyadharas (winged angels), siddhas (super humans), and so on. The Padma Purana mentions there are 400,000 humanoid species in the entire universe.

Bhutas, or ethereal beings. This includes ghosts, bhutaganas (known as grey aliens in the western culture), pisacas (child-eating demon, as Pennywise), goblins, and so forth.

3. Classification based on realms of existence

This classification is found in the Bhagavata Purana, Canto 3 and 5. Heavenly realms are planets where devas, siddhas, caranas, vidyadharas, kinnaras and all good beings reside. Then, subterranean planets or the bila-svargas are planets where asuras, krimayas, reptilians and bhutas live. In between is the Earthly plane, or the Bhurloka, where spirits take birth and do particular activities for further entanglement in material existence or go back to Godhead.

4. Classification based on chemical compounds and molecular basis.

This kind of classification is a combination between physiology and basic element(s) in the cells. For example, a mammal in a particular planet may be composed of different element from mammals on Earth. Such element might not be carbon (as dominant in Earth mammals' cells) but could be silicon, silver or copper. This anomaly is found in chemical compound of some Earth mollusks such as shrimp, whose blood contain copper element rather than iron, which thus makes their blood bluish.

In the Mahabharata, as well as the Rigveda it is stated that Garuda's feather is made of special compound that could neutralize thunderbolt effect. Some Vedic Scriptures name it as suvarnapaksa, or 'golden-winged bird'. It could be concluded that Garuda's basic cellular element is gold (aurum) and calcium compound, unlike Earth birds, although they physiologically belong to the same avian species.

\section{Conclusion}

Descriptions and lists of extraterrestrial beings in the Vedic Scriptures certainly reveals outstanding fact about depth, vastness and honesty of the Vedic knowledge. Their existence and interactions with human beings as recorded in the Vedic literature especially the Puranas and Itihasas prove that their existence is undeniable in the Vedic civilization.

\section{References}

Anonymous 2008. Sri Brahma Samhita, with the Commentary Dig-Darsani-Tika of Sri Jiva Gosvami. Mumbay: Bhaktivedanta Book Trust International.

Anonymous. 2010. Padma Purana [Veda, online], http://www.sacredtexts.com/hin/, accessed on $18^{\text {th }}$ of October 2017.

Anonymous. 2010. Matsya Purana [Veda, online], http://www.sacredtexts.com/hin/, accessed on $18^{\text {th }}$ of October 2017.

Anonymous. 2017. Rigveda Samhita [online]. Sacred text, $6^{\text {th }}$ of December 2017, 20:15 UTC [dikutip 10 
Desember 2017]. Available at http://www.sacred-

texts.com/hin/rvsan/index.htm.

Anonymous. 2017. Mahabharata [online]. Sacred text, $6^{\text {th }}$ of December 2017, 21:35 UTC [quoted $10^{\text {th }}$ of December 2017]. Available at http://www.sacredtexts.com/hin/maha/

Backster, Cleve. 2003. Primary Perception: Biocommunication with Plants, Living Foods, and Human Cells. Anza, CA: White Rose Millenium Press.

Bhumipati Dasa. 2014. Bhavisya Purana [Veda]. Vrindavan: Rasbiharilal \& Sons Publisher.

Cremo, Michael dan Richard L. Thompson. 1998. Forbidden Archeology: the Hidden Hostory of the Human Race. Badger: Bhaktivedanta Book Publishing.

Daniken, Erich Von. 1969. Chariots of the Gods?. New York: Michael Heron and Souvenir Press.

Daniken, Erich Von. 1979. Adakah Hubungan dengan Makhluk Luar Angkasa [Indonesian translation]. Bandung: Tanadi Foundation.

Debroy, Bibek dan Dipavati Debroy. 2002. Brahmanda Purana. Surabaya: Paramita Publisher.

Eternalreligion.org, 2012.Vedic Creation Chart [bagan, unduhan]. www.eternalreligion.org, accessed on $10^{\text {th }}$ of May 2017.

Forti, Kathy J. 2017. African Dogon Tribe Reveals Man's True Origins [daring], http://www.trinfinity8.com/africandogon-tribe-reveals-mans-true-origins/, accessed on $31^{\text {st }}$ of September 2017.

Greene, Brian. 2003. The Fabric of the Cosmos. New York: Alfred A. Knopf.

Hidell, Al. 1998. Complete Conspiracy Reader. New York: MJF Books.

Jones, Gwyn. 1984. A History of the Vikings. New York: Oxford University Press.

Madhavananda Dasa. 2006. Is Lanka the Lanka of Ramanaya? [online]. http://www.dandavats.com/?p=28166, diakses pada $20^{\text {th }}$ of October 2017.
Prabhupada, A.C. Bhaktivedanta Swami. 1978. Easy Journey to Other Planets. Mumbay: Bhaktivedanta Book Trust International.

Prabhupada, A.C. Bhaktivedanta Swami. 1979. Life Comes from Life. Mumbay: Bhaktivedanta Book Trust International.

Prabhupada, A.C. Bhaktivedanta Swami. 2003a. Bhagavad-gita Menurut Aslinya. Jakarta: Hanuman Sakti.

Prabhupada, A.C. Bhaktivedanta Swami. 2003b. Srimad Bhagavatam (Canto 110). Mumbay: Bhaktivedanta Book Trust International.

Prema Rasa Dasa dan Sandipani Muni Dasa. 2004. The Book of Samskaras (Purificatory Rituals for Successful Life). Mumbay: Bhaktivedanta Book Trust International.

Purnaprajna Dasa. 2005. Hari Bhakti Vilasa of Srila Sanatana Gosvami [Veda] (editor edisi: Purnaprajna Dasa). Vrindavan: Rasbiharilal \& Sons Publisher.

Purnaprajna Dasa. 2009. Stories from the Visnu Purana. Vrindavan: Rasbiharilal \& Sons Publisher.

Purnaprajna Dasa. 2013. Words of Wisdom from the Puranas. Mumbay: Bhaktivedanta Book Trust International.

Purnaprajna Dasa. 2014. Mahabharata an Authentic Presentation. Delhi: Sri Sitaram Seva Trust.

Redfern, Nick. 2016. Weapons of the Gods. Wayne: New Page Books.

Rosenthal, Alex and George Zaidan (producer). 2013. Exploring Other Dimensions, TED-Ed, New York, NY, 4 mnt $48 \mathrm{~s}$.

Sagan, Carl (producer). 1980. Cosmos: A Personal Voyage, Carl Sagan Productions with BBC, 60 mnt per episode (13 episodes).

Santillana, Georgio de dan Hertha von Dechend. 2015. Hemlet's Mill (ebook). Liverpool: Nonparell Books.

Singh, T.D. 2003. Vedanta and Science Series Vol. 1: Life and Origin of the 
Universe. Kolkata: Bhaktivedanta Institute.

Singh, T.D. 2004. Vedanta and Science Series Vol. 2: Reality of God's Existence. Kolkata: Bhaktivedanta Institute.

Sitchin, Zecharia. 2002. The Lost Book of Enki. Rochester, VT: Inner Traditions - Bear \& Company Publishing.

Sitchin, Zecharia. 2014. The Twelfth Planet (Book 1 of the Earth Cronicles). Rochester, VT: Inner Traditions - Bear \& Company Publishing.

Thakura, Bhaktivinoda. 2006. Jaiva Dharma [versi digital]. Orissa: Gaudiya Matha Publication.

Thompson, Richard L. 1995. Alien Identities: Ancient Insights into Modern UFO
Phenomena. Alachua: Govardhan Hill Publisher.

Thompson, Richard L. 2004. Vedic Cosmography and Astronomy. New Delhi: Motilal Barnasidass Publisher, Ltd.

Tilak, Bal Gangadhar. 1893. Orion and the Antiquity of the Vedas. Bombay: Radhabai Atmaram Sagoon Bookseller and Publisher.

Wiguna, I. M. A. (2018). The Perception Of Hindus In Denpasar City To The Abolition Of Sin In The Text Of Siva Puraana. Vidyottama Sanatana: International Journal of Hindu Science and Religious Studies, 2(1), 119-131. 